\title{
RAISE OF ROLE OF THE COURT IN THE MUNICIPAL LEGAL LIABILITY MECHANISM
}

\author{
Tatiana N. Mikheeva ${ }^{1 *}$ and Olga B. Bakanova ${ }^{2}$ \\ ${ }^{1}$ Prof.Dr, Mari State University, The Russian Federation, tnmiheeva @marsu.ru \\ ${ }^{2}$ Postgraduate, Mari State University, The Russian Federation, law @marsu.ru \\ ${ }^{*}$ Corresponding Author
}

\begin{abstract}
The issues of responsibility of bodies and officials of local self-government are of constant interest among researchers. Responsibility in this area is characterized by its own particular qualities, since the current legislation in the mechanism for bringing to justice includes both court and some state bodies. The aim of the study is to substantiate the need to exclude non-judicial bodies from the complex procedure of municipal legal responsibility. The analysis of such types of responsibility as the dissolution of the representative body of the municipality, the dismissal of the head of the municipality or the head of the local administration shows that the court is given insignificant position in them. The final decisions in relation to the subjects listed below are made by the heads of the regions or regional parliaments. In these cases, the principle of independence of local self-government is violated, but also there are reasons to doubt the objectivity and impartiality of decisions of state authorities. The result of study is the conclusion of exclusion of non-judicial state structures from the number of entities authorized to prosecute local government bodies and officials. Proposals of leaving the court itself in the mechanism of municipal-legal responsibility are substantiated; this corresponds to the principles of the rule of law and the world practice of democratic states.
\end{abstract}

Keywords: local government, municipal and legal responsibility, court.

\section{INTRODUCTION}

The responsibility of bodies and officials of local self-government in municipal law is subdivided into: a) to the population, c) to the state, $\mathrm{c}$ ) to legal entities and individuals. It seems to be the most important to investigate the first two types of responsibility since they are the most specific.

Among scientists there is no single approach to the definition of this institution. For instance, a number of researchers have a prevailing opinion that only the responsibility of bodies and officials to the population should be attributed as a municipal legal and the responsibility of these entities to the state should be considered constitutional and legal (Shugrina, 2016, p. 46). However, there is another point of view which in general is quite convincingly formulated in the legal literature. Municipal legal liability is a departmental type of legal liability of municipal law, which occurs for violation of functions or failure to fulfill the tasks assigned by the legislator to the municipal level of government (Chadov, 2016, p. 14). Let us clarify that the overwhelming majority of the functions and tasks of local self-government are aimed at resolving issues of local importance. This gives grounds to distinguish between municipal legal responsibility and constitutional legal responsibility, which is a convincing argument in favor of an unambiguous understanding of the responsibility of bodies and officials at the municipal level.

There is another interesting perspective on understanding the issue under study. The subjects of municipal 
legal responsibility are the representative bodies of municipalities, heads of municipalities and local administrations. Those subjects being «responsible» within the framework of the powers granted justify the rights given to them. In cases of «irresponsible» behavior it is assumed that appropriate sanctions will be introduced, which limit the independence and autonomy of the municipality (Islamov, 2019, p. 41). As the abovementioned sanctions, municipal legislation provides for certain various adverse consequences in the form of early termination of the powers of bodies or officials (dissolution of a body, removal from office, recall).

Thus, the specificity of the institution of municipal-legal responsibility lies in the subject composition (only bodies and officials of local self-government) and sanctions possessed by municipal law only. Meanwhile, there are also significant differences in the procedural issues of bringing subjects to justice. This mechanism includes the population of the municipality (responsibility to the population) and state bodies - the head and the legislative body of the subject of the Russian Federation (responsibility to the state). Mandatory for all of these cases is the confirmation in court of the illegality of the actions or the unlawfulness of the decisions of the bodies and persons brought to justice.

The research focuses on examining the features of various types of municipal legal responsibility and the role of the court in the complex mechanism of bringing to responsibility.

\section{RESULTS AND DISCUSSION}

Municipal law as a branch of Russian law is distinguished by functions belonging to it and subjects of legal relations characteristic for it only and therefore, this branch needs its own kind of legal responsibility. Such responsibility has a specific purpose, unique grounds for the occurrence (which are municipal tort); a special procedural form and procedure for its implementation, special categories of subjects that can be involved in it (Chadov, 2016, p. 15). The peculiarity of municipal legal responsibility lies in the fact that it is applied in relation to local government bodies (representative body) or individual elected or appointed officials of these bodies (deputies of a representative body, the head of the municipal formation or the head of the local administration).

An important role in prosecuting municipal officials is given to the population since local self-government determines the people, the population of municipalities, as the main carrier of power and local authorities are the subject formed by the population (Mikheev \& Mikheeva, 2016, p. 120). Local self-government bodies are in a representative legal relationship with the population of the municipality regardless of the order of their formation (Belousov \& et.al, 2015, p. 59). The activities of local authorities are as close as possible to the population and their results directly affect the quality of life of citizens (Mikheeva, 2018, p. 177).

In this regard, it seems logical that the population participates in bringing certain officials of the municipal level to justice. Responsibility to the population extends to the deputy of the representative body of the municipality or other elected officials of local self-government, for instance, to the head of the municipality. The content of this type of responsibility is directly related to the way in which the named persons are empowered - with their election in municipal elections. Adverse consequences (sanction) are the recall of the elected official by the voters. The withdrawal procedure itself consists in voting of citizens for the recall of the person brought to justice. The grounds for this can only be his illegal decisions or actions (inaction).

The facts of violations by the deputy or other recalled person must be confirmed in court. The inclusion of the court in the liability mechanism acts as a guarantee of qualified consideration of the revealed unlawful decision or action and its legal assessment by the justice body. In practice, it is impossible to exclude precedents when citizens who have come forward with the initiative to withdraw may be mistaken about the guilt of the subject of municipal responsibility or the unlawfulness of his actions. In this case, judicial protection applies to all parties involved in this legal relationship: citizens, a deputy or another elected official.

The complexity of the situation lies in the fact that the Federal Law «On General Principles of Organization of Local Self-Government in the Russian Federation» (Federal Law No. 131-FZ, 2003) did not establish clear grounds for revocation, but gave the municipalities the right to determine in the charter their list and the procedure for resolving issues in terms of responsibility to the population. In practice, some statutes set too wide basis for a revocation procedure. In the legal literature on this matter opinions are expressed about the limitation of such grounds only to the framework of the exercise of official powers. In this case, the violation should be systematic or one-time, but rough (Trofimova, 2016, p. 229).

Thus, speaking about the features of the mechanism of responsibility to the population, the following should be emphasized. The main initiator of the revocation and in the future the main subject making the decision on revocation by voting is the population of the municipality. The court here performs an important, but 
intermediate function of establishing the unlawfulness of the decision (action) of an elected official.

Responsibility to the state extends to the representative body of the municipality, the head of the municipality, and the head of the local administration. The forms of municipal legal responsibility in this case are respectively the dissolution of the representative body, the removal from office of the above-named persons.

The institution of the dissolution of a representative body can be applied on two grounds. Firstly, in case of non-execution of court decisions, this established contradictions between a normative legal act of this body and legal acts of a higher legal force. Secondly, it is the failure of the representative body to hold its meeting for three consecutive months. In both cases, the decision for dissolution requires a preliminary trial to establish the fact of the offense.

The powers of the court in such cases are not only in establishing the fact of contradiction of the contested legal act. P.A. Astafichev believes that the court session should clarify all the circumstances in full, which follow from the procedural nature of the judicial authorities. The court is obliged to establish whether the rights, freedoms or legitimate interests of the plaintiff or the persons in whose interests the claim is filed have been violated. The court must establish the presence or absence of compliance of the contested act with legal acts of higher legal force. In addition to this, the law imposes on the court the obligation to find out whether a number of requirements for the contested act have been complied with: the authority of the body, the form and type of the act, the procedure for its adoption, and the rules for enactment. As a result, not only the content of the contested act (substantive law), but also the procedure for its adoption (procedural law) is being checked (Astafichev, 2018, p. 41).

The importance and necessity of the stage of litigation in the mechanism of dissolution of the representative body of the municipality is obvious. It is a guarantee of the protection of the rights of both the applicants and the representative body itself. Only after a court verdict has been passed and in the event that it is ignored by a representative body, the head of a constituent entity of the Russian Federation comes up with a legislative initiative to dissolve this body. The final decision in the procedure for bringing to justice belongs to the legislative body of the subject of the Russian Federation which adopts the law.

The legal algorithm for bringing to justice established by Federal Law No. 131-FZ is subject to valid criticism. For instance, Solovyev S.G. proposes to supplement the mechanism of dissolution of the representative body with preliminary procedures. This may be a warning from a higher state body about the possibility of dissolution, a public discussion of this warning with the public of the municipality and others (Solovyev, 2019, p. 48).

However, there are reasons in general to doubt the correctness of including the head and the legislative body of the subject of the Russian Federation in this mechanism. After the court has made a decision on the illegality of the legal act of the representative body and the body does not accept the court decision for execution, it seems legally justified to hold a subsequent court session. After establishing the fact of nonexecution of the court decision, a sanction is imposed on it in the form of the dissolution of the representative body.

The main argument in favor of such a proposal is the rule of law in a state governed by the rule of law which presupposes a real opportunity for every person to appeal against any illegal decisions in courts (Mikheeva, 2013 , p. 31). Therefore, it seems unacceptable to include in the process of bringing a representative body to justice along with the judicial stage of the above-mentioned «political» stages.

The legislative procedure for bringing the head of the municipal formation and the head of the local administration to account before the state is not much different from the previous one. Also, at the first stage the court establishes the illegality of the named officials of legal acts or their commission of illegal actions, for instance, misappropriation of budget funds. At the second stage, the head of the subject issues a sole legal act on the dismissal of the head of the municipal formation or the head of the local administration.

By analogy with the previous proposal, it also seems expedient to exclude the second stage from the mechanism of bringing to justice, leaving the function of removing the guilty municipal persons from office only to the court.

\section{CONCLUSION}

One of the signs of the rule of law is the division of state power into legislative, executive and judicial. Each branch of government has its own inherent functions. The study revealed that the judicial authorities, as well as the state bodies of the constituent entity of the Russian Federation - the legislative body, the head of the 
constituent entity - are involved in the mechanism of bringing to responsibility the representative body of the municipal formation, the head of the municipal formation and the head of the local administration. In this case, there is a mixture of judicial, legislative and executive functions. The legislative body in addition to the basic legislative powers, invades the judicial sphere and essentially makes a decision (imposes a sanction) for the illegal actions of the representative body of the municipality. A similar situation is observed in the actions of the head of a constituent entity of the Russian Federation, who single-handedly makes a verdict on the dismissal of municipal officials. Thus, he replaces the judiciary, which is responsible for the administration of justice.

The institute of responsibility of bodies and officials of local self-government to the state in connection with the identified conflicts requires improvement. The functions of making a decision, which are essentially judicial in nature, which are unusual for the legislative and executive structures, should be transferred to the court. We propose to amend Articles 73 and 74 of Federal Law No. 131-FZ, excluding from the mechanism of bringing to responsibility of municipal bodies and officials such representatives of state power of the constituent entity of the Russian Federation as the legislative body and the head of the constituent entity.

At the same time, it seems expedient to retain the name of the type of responsibility as responsibility to the state, since the court also acts as an organ of state power. The function of the court acquires a complete character: a) establishing the presence of wrongfulness and guilt in decisions, actions of a municipal body or an official c) issuing a sanction in the form of dissolving the body or dismissing a person from office.

The likelihood of a qualified and impartial judgment taking into account all the circumstances is increased. It is also important to exclude the possibility of state authorities to manipulate municipal authorities, to put pressure on them.

\section{REFERENCE LIST}

Astafichev P.A. (2018). The Party System and Issues of Elerctoral Democracy in Russiadissolution of the Representative Body of Local Self-Government as a Municipal Law Institution. Constitutional and municipal law, vol.3, p.39-44.

Belousov E.I., Gornev R.V.\& Mikheeva T.N. (2015). About Participation of Institutes of Civil Society in Public Control over the Activities of Local Authorities. Review of European Studies, vol. 7. DOI:10.5539/res.v7n8p59.

Chadov A.V. (2016). Municipal and Legal Responsibility as an Independent Type of Legal Responsibility. Municipal service: legal issues, vol.4. p. 13-16.

Federal law of October 6, 2003 № 131-FZ "About the general principles of the organization of local selfgovernment in the Russian Federation" (2003). Russian Federation Code, vol.40.

Islamov A.M. (2019). Liability in the Local Self-Government System as a Form of Implementation of the Principle of Independence of Municipal Structures. State power and local self-government, vol. 9, p.40-44.

Mikheev D.S. \& Mikheeva T.N. (2016). Publicity Role in Implementation of Public Control at the Municipal Level. Bulletin of the Russian Univercity of Cooperation, vol. 1 (23), p.120-123.

Mikheeva T.N. (2018).Public Control from the Standpoint of the Constitutional Right of Citizens to Participate in the State Affairs Management. Actual Problems of Russian Law, vol. 10 (95), p. 177-183. DOI: 10.17803/1994-1471.2018.95.10.177-183

Mikheeva T.N. (2003). The principle of the rule of law at the present stage of development of the constitutional state. Law and right, № 9. P. 29 - 31.

Shugrina E.S. (2016). Control, responsibility and judicial protection of local self-government. Moscow: «Delo» Publishing House. 2016. 220 p.

Solovyev S.G. (2019). On the No-Fault Liability of a Local Representative Authority. State power and local self-government, vol. 6, p. 17-22.

Trofimova G.A. (2016). Constitutional Responsibility of Local Government Bodies and Officials: Problems of Theory and Legal Regulation. Administrative and Municipal Law, vol. 3 (99), p. 223-233. DOI: 10.7256/ 1999-2807.2016.3.16139 